\title{
The St. John and Paul hospital in Venice
}

\author{
Michele Alzetta
}

Received: 31 August 2010/ Accepted: 12 October 2010/Published online: 10 November 2010

(C) Springer-Verlag 2010

Tourists reaching the Campo San Giovanni e Paolo in Venice are often surprised at seeing what seem to be two great churches next to one another; even more surprised when they discover that the "Church" with the most elaborate and beautiful façade is actually the principal entrance of St. John and Paul Civil Hospital, to the right of which a much less impressive although larger building is the church of Saints John and Paul. Venice's hospital consists of various modern buildings and of four historical ones: the Scuola Grande di San Marco, the Dominican Convent, the Hospital of San Lazzaro e Mendicanti and the church and convent of Santa Marta del Pianto. Several books have been written on the history of the hospital and of the health system in Venice, and historical research is still active (Figs. 1, 2).

\section{The first Venetian hospital and the Scholae Magnae}

Venice was an independent republic for over 1,000 years (727 A.D.-1797 A.D.) and an organized health care system developed very early. In 1224, a hospital for Lepers, dedicated to St. Lazarus, was already present in Dorsoduro. In 1262, it was moved to an island in the Venetian lagoon now known as "Lazzaretto Vecchio". In 1468, on a different island, called "Lazzaretto Nuovo" a new system for the prevention of the spread of contagious disease was implemented: potentially infected goods and people were kept in isolation for a period; if plague or some other

M. Alzetta $(\bowtie)$

Emergency Unit SUEM, Saint John and Paul Hospital, Castello 6777, Venice, Italy

e-mail: michele.alzetta@ulss12.ve.it disease developed they were transferred to the Lazzaretto Vecchio, otherwise they were released. This was probably the first place in Italy where quarantine was instituted. The island of San Lazzaro, which has since become an important center of the Armenian culture, had a similar function for a period.

In the rest of Italy "Ospitali" were often created by confraternities, and initially gave hospitality to pilgrims and aid to the needy and to ill people. Some of these "Ospitali" with time developed into modern hospitals. In Venice, the role of the confraternities was taken by the "Schools" (Scuole), which were religious associations of lay people, governed by elected functionaries and regulated by statutes approved by the public authorities which bound members to the practice of charity. The Schools were divided into Great (Scholae Magnae) and Minor, these last often related to specific arts or professions. The six Major Schools vied with one another in the practice of charity and

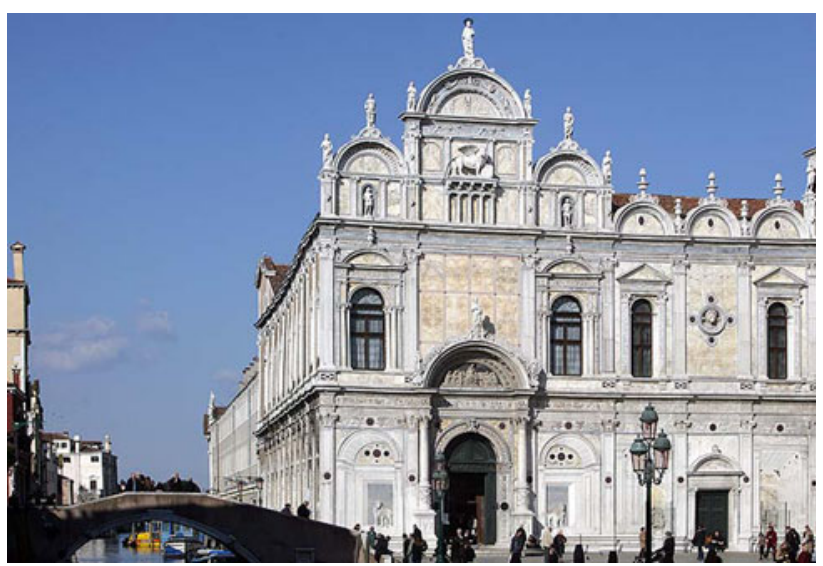

Fig. 1 The façade of the School of St. Mark, now principal entrance to the hospital (photo by Daniele Resini) 


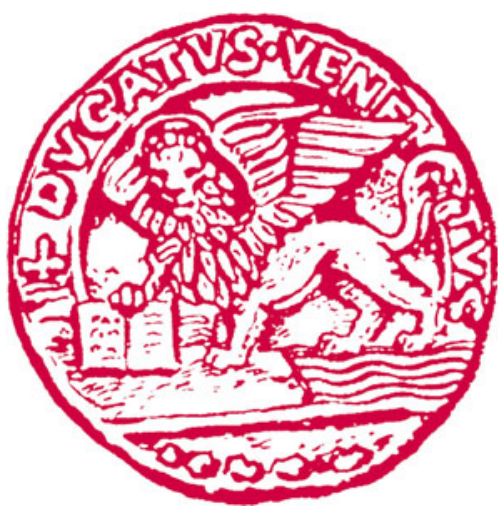

Fig. 2 Logo of the hospital

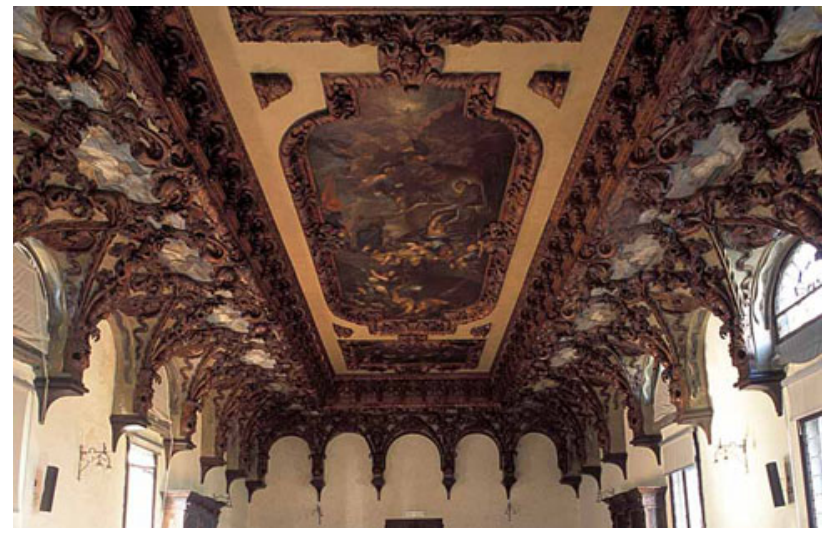

Fig. 3 View of the ceiling of the library of Saint Domenic's convent, now a reunion hall for the hospital (photo by Daniele Resini)

in the magnificence of their buildings. So it was that the School of St. Mark, founded in Santa Croce in 1260, in 1437 obtained land from the Dominicans and moved to the present site, adjacent to their convent (Fig. 3). In 1485, a fire destroyed the building of the Scuola Grande di San Marco, and the Senate of the Republic decided to give the necessary funds to build a new and larger building, which is still extant and is now the principal entrance to the hospital.

\section{Development of the health care system in Venice}

In 1478, the plague had devastated Venice and as a consequence in 1485 three "Ministers of Health" ("Provveditori alla Sanità") were appointed and progressively endowed with increasing powers. In 1505, the Provveditori alla Sanità were given criminal jurisdiction and could give even the most severe of penalties. They had power over hospitals, urban hygiene, food, beggars, prostitutes, hotels, burials and over the associations of doctors, physicians and barbers. Given their increasing importance from 1537 they were no longer appointed by the senate, but by the governing council of Venice ("Maggior Consiglio") itself, and their number was brought to five in following years by the addition of two Sopraprovveditori. With the third great epidemic of plague the need was felt for these officials to become particularly competent in health care and hygiene. These Magistrates constantly consulted doctors and physicians and tried to keep up to date on new developments. Elsewhere health care became exclusively concentrated in hospitals, whereas in Venice a network of "Uffici di sanità" was created in each district of the town (Sestriere). These were active in various aspects of public hygiene and were also responsible for organizing local emergency care. In 1767, the Dutch Society for Recovery of Drowned Persons was founded in Amsterdam, and in the following years humane societies which aimed at resuscitating the drowned rose in various countries, but in Venice this was not left to voluntary initiatives: an organized system was established by law in 1768 and the material necessary for lifting the drowned from water and for ventilation was made publicly available in multiple points of the town and of each of the more important islands. A precise procedure for the reanimation of the drowned was defined, severe penalties for those who omitted these maneuvers established and in case of successful reanimation a prize in money given.

The Venetian organization of health care was suppressed with the conquest of Venice by Napoleon in 1797.

\section{The "San Lazzaro e Mendicanti" Hospital}

As leprosy was becoming less prevalent in 1595 the Maggior Consiglio decided to move the hospital from the island of San Lazzaro to a site next to the Scuola di San Marco and to the convent of the Dominicans. This was still an "Ospitale" in the ancient sense of the word, providing not only health care, but also social assistance to orphans, elderly and poor. For this reason its name was changed to "San Lazzaro e Mendicanti" for it was meant to face the problem of poverty as much as that of disease. It was only in the eighteenth century that a profound transformation began to take place in the role of hospitals, which became places exclusively dedicated to the treatment of the ill.

\section{From the end of the Venetian Republic to the present}

In 1797, the Republic fell to Napoleon, religious orders and associations were banned, and the building of the Scuola Grande di San Marco together with the convent of the Dominicans and the Ospedale di San Lazzaro e Mendicanti were united to form a military hospital. Venice later came 


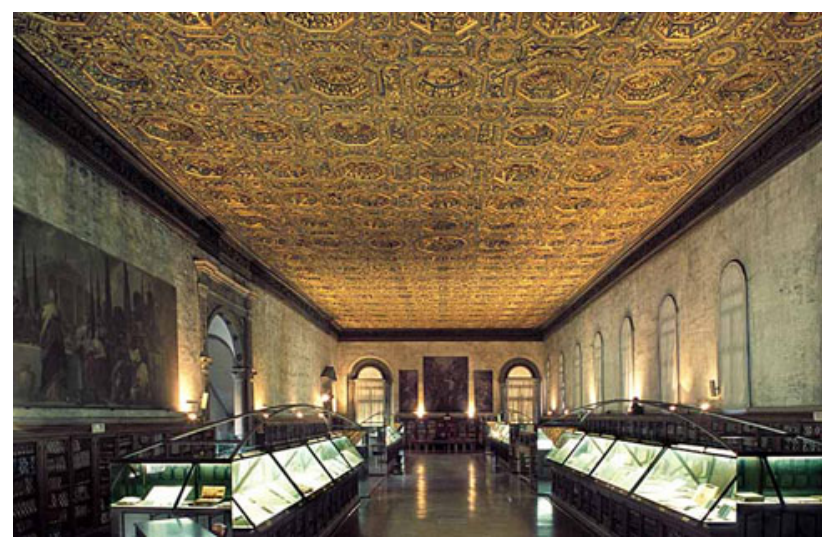

Fig. 4 The historical library on the first floor of the School of St. Mark (photo by Daniele Resini)

under Austrian rule, and in 1819 the complex of buildings became a Civil Hospital. In the nineteenth century a school of Obstetrics, a "Practical School of Medicine" for doctors who had recently obtained their degrees and a school of nursing were established. In 1964, Le Corbusier was asked to make a project for a completely new hospital which was, however, never built. New spaces for the old hospital were created in the twentieth century by adding a series of modern buildings to the historical complex, and the hospital gradually grew to the present situation in which it has all modern specialty wards and services except for neurosurgery and cardiosurgery, for which patients are sent to the new "Ospedale dell'Angelo" in Mestre (mainland Venice). In 1972, another ancient building was added to the hospital complex: the convent and church of Santa Maria del Pianto.

\section{Art and architecture}

The works of art to be found in the ancient buildings are too numerous to describe in detail, so only a few will be mentioned. The Scuola Grande di San Marco, now the principal entrance to the hospital, has a beautiful marble façade built by Pietro Lombardo and by Giovanni Buora, who included statues from the older building which had been destroyed by fire in the entrance. In 1494, the façade was completed by Mauro Coducci, who added the characteristic superior arches (Fig. 1).

The huge hall on the first floor is now a historical library, open to the public, containing a collection of ancient books and medical instruments and several paintings, among which various by Domenico Tintoretto ("St. Mark's body brought to the venetian ship", "The arrival in Venice of the ship with St. Mark's body" and "The

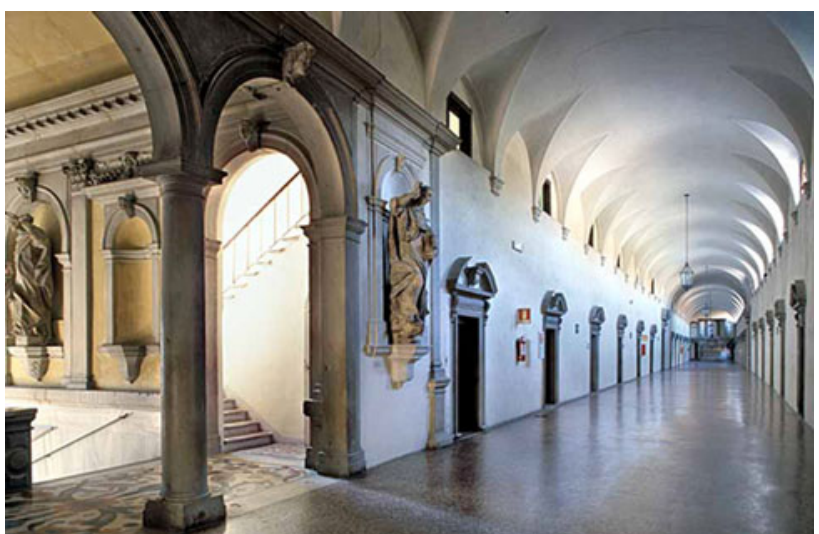

Fig. 5 A view of the corridor of the ancient convent of St. Domenic, which now hosts administrative offices and ambulatory services (photo by Daniele Resini)

apparition of St. Mark's relic in the Basilica") and Jacopo Palma il Giovane ("Christ in glory and the saints Mark, Peter and Paul") Several other paintings have been taken from here to the Accademia museum in Venice or to the Brera museum in Milan. The ceiling is also worthy of note, being of carved wood inlaid with gold (Fig. 4). The church of San Lazzaro, which is still the church of the hospital, has a marble façade and contains a monument in honor of Luigi Tommaso Mocenigo, hero of the Candia war, by Giuseppe Sardi.

The layout of the hospital is such that public walkways pass in the middle of the buildings and through the cloister of the Dominican convent (Fig. 5), and by venetians it is felt not as an isolated complex of buildings but as part of the town itself.

\section{Suggested Readings}

1. L'Ospedale dei Veneziani. Storia-Patrimonio-Progetto, tip. Commerciale, Venezia 1986 - Nelli-Elena Vanzan Marchini

2. Le leggi di sanità della Repubblica di Venezia, (edizione critica), a c.di Neri Pozza, Vicenza 1995

3. Le leggi di sanità della Repubblica di Venezia, (edizione critica) tomo II*, a c. di Neri Pozza, Vicenza 1998

4. Le leggi di sanità della Repubblica di Venezia, (edizione critica) tomo III*, a c. di Canova, Treviso 2000

5. La Scuola Grande di S.Marco. I saperi e l'arte, (a cura di), Canova, Treviso 2001

6. Le leggi di sanità della Repubblica di Venezia, (edizione critica cura di) tomo IV*, a c. di Canova, Treviso 2003

7. Tutela della sanità e ambiente nella Repubblica di Venezia, in Atti del XXXI Congresso Internazionale di Storia della Medicina, a c. di R.A.Bernabeo, Bologna 1990, pp 1057-1067

8. Mostra: Rotte mediterranee e baluardi di sanità; Venezia e i lazzaretti mediterranei. Biblioteca Nazionale Marciana. Sale Monumentali (Libreria Sansoviniana) 31 marzo - 11 luglio 2004 